\title{
Arginine Synthesis in Neurospora crassa; Genetic Studies
}

\section{BY DOROTHY NEWMEYER}

Department of Biological Sciences, Stanford University, Stanford, California, U.S.A.

SUMMARY : Nine mutants of Neurospora crassa which require arginine as a nutrient but cannot use citrulline were obtained from various sources. These fall into two classes, according to location in linkage group I or VII. (Enzymic tests, reported elsewhere, indicate that the two classes of mutants affect the enzymes which control the two reactions between citrulline and arginine.) Heterokaryon tests between mutants of the same group were negative, and crosses between mutants of the same group were semi-sterile, most of the ascospores being non-viable. Crosses between the five group I mutants produced no $\mathrm{arg}^{+}$progeny, and separate mapping tests on four of them indicate that they are either allelic or closely linked. All crosses between the group VII mutants gave many $\arg ^{+}$progeny. For the one pair of mutants which was studied in detail, origin of the $\mathrm{arg}^{+}$by means other than crossing-over (or gene conversion) has been virtually eliminated. However, mapping studies place the two mutants only $0-6$ units apart. It is concluded that the high $\mathrm{arg}^{+}$frequency is due to selection, and that the mutants might be pseudoalleles.

In recent years several enzymic studies have been made in order to test directly the hypothesis that there is a one-to-one relationship between genes and enzymes (Beadle, 1945). Unfortunately, relatively few of these studies have been made on organisms in which it could be established that the mutant phenotype was really due to a single gene, and in these few cases there has usually been only one mutant available for study. A more critical test is provided when a series of similar mutants is studied; such tests are also needed to settle the controversy about whether pseudoalleles control the same or different reactions. However, in the case of biosynthetic enzymes, material suitable for such a test is so rare that very few cases of this sort have been reported (Yanofsky \& Bonner, 1955; Fincham, 1950, 1954). The present study is an attempt to provide two more such cases.

The conversion of citrulline to arginine in mammalian liver has been shown by Ratner and co-workers (Ratner, Anslow \& Petrack, 1953; Ratner \& Petrack, 1953) to consist of at least two reactions:

$$
\text { citrulline + aspartate } \stackrel{\mathrm{Mg}^{++}+\mathrm{ATP}}{\longrightarrow} \text { argininosuccinate } \rightarrow \text { arginine + fumarate }
$$

The first step requires two enzymes, both of which must be present to produce any detectable effect. An enzymic study of wild type Neurospora crassa (Newmeyer, unpublished) showed that it converted citrulline to arginine in the same way as liver, except that there is no evidence yet that two enzymes are required for the first reaction. Independently, Drs Fincham \& Boylen (personal communication) have obtained preliminary evidence for the same reaction sequence in Neurospora crassa, and they have studied the second reaction in detail (Fincham \& Boylen, 1957). 
This system seemed ideal for the type of test described above, because nine mutants were available which might be expected to fall into two or three genetic groups corresponding to the two or three enzymes involved. Furthermore, if pseudoalleles ever do control sequential reactions requiring close proximity of two gene-products (as discussed by Pontecorvo, 1955, and by Lewis, 1955), the conversion of citrulline to argininosuccinate should be an excellent place to look for it.

The present paper reports a genetic study of the nine arginine-requiring mutants. Each segregates as though a single mutant gene is involved. Genetically they fall into two classes, located in linkage groups I and VII; preliminary enzyme tests on one member of each class indicated that the group I mutant affects the first reaction and the group VII mutant affects the second (Newmeyer, unpublished).

The group VII mutants were sent to Drs Fincham \& Boylen for study; their results, reported in the accompanying paper (Fincham \& Boylen, 1957), indicate that all four mutants lack the enzyme which catalyses the second reaction. For their results to be most meaningful, it is necessary to know whether these mutations involve the same or different genes. Much of the present paper is devoted to an attempt to answer this question. Because of sterility difficulties, it has been necessary to restrict this work to two of the mutants; these appear to be either pseudoallelic or closely linked.

A similar study of the group I mutants is still in progress. Enzymic tests (Newmeyer, D. \& Högström, D. unpublished) indicate that all members studied thus far affect the first reaction. The genetic tests to date, which are reported here, indicate that all five mutants may be alleles.

\section{METHODS}

\section{Arginine-requiring mutants}

Origin. Only two mutants of Neurospora crassa which can use arginine but not citrulline have been reported previously; these are 36703T (arg-1) and 46004, described by Srb \& Horowitz (1944) and Srb (1946). Seven others were obtained by screening new mutants from various sources. Mutant $\mathrm{H} 4250$ was kindly provided by Dr F. P. Hungate, who isolated it after treatment with ${ }^{35} \mathrm{~S}$ (Hungate \& Mannell, 1952). Particular thanks are due to Dr V. W. Woodward, who supplied seventy-two unclassified arginine mutants for testing, of which six were the desired type. Of these, mutants B312 and B317 were isolated after ultraviolet treatment, and mutants B 362, B 368, B 369, and B 370 after gammairradiation. The method for obtaining the last four mutants was such that two or more of them might possibly have arisen from a single mutated nucleus; however, the data reported here show that mutant B 369 is genetically different, and suggest that the other three are independent also. Examination of a total of nineteen additional arginine mutants, kindly provided by Mr R. W. Colburn, by Dr C. M. Stevens, and by Dr R. W. Barratt, yielded none of the desired type.

Genetic basis. The evidence that the arginine requirement of a given mutant segregates as a single Mendelian factor is based on the ratio of $\mathrm{arg}^{+}:$arg $^{-}$ 
random isolates in crosses to wild type (or to other $\arg ^{+}$strains). For each mutant, Table 1 gives the pooled results of all such crosses in which the degree of germination was high enough $(\geqslant 70 \%)$ to minimize skewing of the results. Eight of the mutants gave the expected 1:1 ratio. In the case of the ninth mutant (B312), it is concluded that the deviation is due only to differential viability, for the following reasons: (1) the number of non-germinants is sufficient to account for the deviation; (2) if the ratio obtained were due to the segregation of two or more genes, then the cross B312 $\times 30300$ (Table 4) should give a minimum of $10 \% \mathrm{arg}^{+}$progeny; actually it gave $1.0-1.5 \% \mathrm{arg}^{+}$.

Table 1. Segregation ratios

\begin{tabular}{lrrc} 
& \multicolumn{3}{c}{ No. of random isolates } \\
Mutant & arg $^{+}$ & arg $^{-}$ & $\begin{array}{c}\text { Not } \\
\text { germinated }\end{array}$ \\
B312 & 106 & 72 & 30 \\
H4250 & 65 & 63 & $c .20$ \\
46004 & 114 & 119 & 29 \\
$36703 T$ & 171 & 168 & 35 \\
B369 & 62 & 56 & 12 \\
B317 & 143 & 155 & 56 \\
B368 & 52 & 72 & 29 \\
B362 & 49 & 36 & 20 \\
B370 & 244 & 265 & 79
\end{tabular}

Pooled data from various crosses. $P$ values for deviations from 1 arg $^{+}: 1$ arg $^{-}$are greater than $0 \cdot 05$, except for $\mathrm{B} 312$ where $P=c .0 \cdot 01$.

So far, all but two of the mutants appear to be point mutations. Mutant $36703 \mathrm{~T}$ is associated with a translocation (Singleton, 1948), and shows linkage to groups I and V (Srb, cited in Singleton, 1948). There is also strong evidence that mutant $\mathrm{H} 4250$ is associated with some kind of chromosomal aberration (Newmeyer, unpublished). There is no evidence that the arginine requirement of either strain is separable from the aberration. The initial stock of mutant B362 also behaved aberrantly, but this defect was evidently eliminated in the first generation of inbreeding; only apparently normal B362 stocks have been used for enzyme studies or for the crosses reported here.

Inbreeding. All nine mutants were repeatedly back-crossed to wild Neurospora crassa, so that any enzymic differences found could more validly be ascribed to the arginine loci under study, rather than to other differences between the stocks. The wild type Neurospora crassa used for this purpose was STA (also called ST-74 A), which was kindly provided by Dr P. St Lawrence; this strain was also used as the wild type for enzyme experiments, and was the parent of the six mutants isolated by $\mathrm{Dr} \mathrm{V}$. W. Woodward. In each generation an arg- $^{-} a$ isolate was selected and crossed to STA; in the final generation of

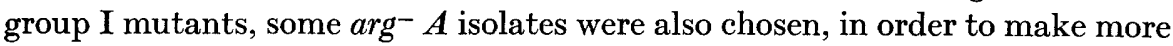
isogenic the short region between arg and sex. All group I mutants were back-crossed for four to seven generations, and all group VII mutants for two to four generations, before being used for enzyme studies.

Relation to other arginine mutants. It will be shown that the strict arginine mutants studied by Srb (1946) are both in group I; the group VII mutants 
apparently represent a previously undescribed locus (or loci). The standard group VII mutant, B317, is not allelic with the unmapped arginine mutants 34105, 21502, 35401 and 44297 (kindly supplied by Mrs M. B. Mitchell). All crosses were highly fertile and produced many wild type progeny. These tests were made even though the unmapped mutants can use citrulline or other precursors, because Mitchell \& Mitchell (1952) showed that the ability of arginine mutants to use precursors is subject to modification by other genes. For similar reasons, the group I mutant 46004 was tested for allelism with 27947 (ornithineless), which was known to be near centromere in either group I or group II (see Barrett, Newmeyer, Perkins \& Garnjobst, 1954); they segregated independently.

\section{Culture methods and markers}

Most of the arginine mutants studied will not grow well on standard complete media unless extra arginine is added; ordinarily $0.5 \mathrm{mg}$. L-arginine $\mathrm{HCl} / \mathrm{ml}$. was added to medium No. 2 of Tatum, Barratt, Fries \& Bonner (1950), or modifications thereof. For crosses carrying the marker button (see below), better germination was obtained on supplemented minimal medium. Crosses were made on 'synthetic crossing medium' (SC) of Westergaard \& Mitchell (1947), usually containing $0.1 \mathrm{mg}$. L-arginine $\mathrm{HCl} / \mathrm{ml}$. Sorbose minimal medium (to induce colonial growth) was used as previously described (Newmeyer, 1954), except that it usually contained only $0.5 \%$ sorbose and $0.1 \%$ sucrose. The minimal medium and standard genetic methods are described by Beadle \& Tatum (1945); special methods will be described in connexion with specific experiments.

Genetic nomenclature and references to previously described markers are given in Barratt et al. (1954). The new colonial marker, button (bn, isolation number B 40), was kindly supplied by Dr D. D. Perkins, who located it in linkage group VII; it was initially isolated by $\mathrm{Dr}$ V. W. Woodward.

\section{RESULTS}

\section{Separation of the mutants into two classes}

Classification according to growth on argininosuccinate (the intermediate between citrulline and arginine) was not possible, because Neurospora is relatively impermeable to this compound (Newmeyer, unpublished), as is Escherichia coli (Walker \& Myers, 1953). However, the nine mutants were readily separated into two classes by linkage, heterokaryon and fertility tests.

The first class, consisting of mutants 36703T, 46004, B312, B369 and H4250, shows linkage to sex (in group I), in agreement with Srb's data for mutant 36703T. Members of the second class (mutants B317, B 362, B368, and B370) show no significant sex-linkage, but are all linked to markers in group VII (the latter class of mutants was first located by Dr D. D. Perkins). Linkage data for both classes are summarized in Table 2. Further evidence for location in group I or VII is given below under Allelism tests for all mutants except B362 and B368; these two were not studied in detail because of the possibility that they arose from the same mutation as B370. 
Heterokaryon tests confirmed the above division of the mutants, and gave no evidence for further subdivision of either group. All possible combinations of either two group I mutants or two group VII mutants gave negligible growth on slopes of minimal medium, but the combination of mutant B 317 (group VII) with any group I mutant gave a definite positive test, as did the combination of mutant B369 (group I) with any group VII mutant. In these tests it seems unlikely that the negative reactions were due to incompatible

Table 2. Data locating arginine mutants in linkage groups I and VII

\begin{tabular}{|c|c|c|c|c|c|c|}
\hline & \multirow{2}{*}{$\begin{array}{c}\text { Arginine } \\
\text { mutant }\end{array}$} & \multicolumn{3}{|c|}{ Group I markers } & \multicolumn{2}{|c|}{ Group VII markers } \\
\hline & & $\operatorname{sex} *$ & $36703 T$ & 46004 & $b n$ & $n t \dagger$ \\
\hline \multirow[t]{5}{*}{ Group I } & $36703 \mathrm{~T}$ & $76 \mathrm{P}: 8 \mathrm{R}$ & - & - & - & - \\
\hline & 46004 & $232 \mathrm{P}: 17 \mathrm{R}$ & - & - & - & - \\
\hline & B 369 & 22P:3R & - & - & - & - \\
\hline & В 312 & $\begin{array}{c}39 \mathrm{P}: 2 \mathrm{R} \\
(5 \text { not scored })\end{array}$ & - & 一 & - & - \\
\hline & H4250 & $\begin{array}{c}57 \mathrm{P}: 10 \mathrm{R} \\
(+9 \text { bisexual })\end{array}$ & - & - & - & - \\
\hline \multirow[t]{4}{*}{ Group VII } & B317 & 7P:111R & $\begin{array}{l}\text { 5PD :3T:3NPD } \\
\text { (41\% recomb.) }\end{array}$ & $\begin{array}{l}36 \mathrm{arg}^{-}: 17 \mathrm{arg}^{+} \\
(64 \% \text { recomb. })\end{array}$ & $36 \mathrm{P}: 16 \mathrm{R}$ & $49 \mathrm{P}: 3 \mathrm{R}$ \\
\hline & В370 & $19 P: 14 R$ & - & $\begin{array}{l}55 \mathrm{arg}^{-}: 16 \mathrm{arg}^{+} \\
(45 \% \text { recomb. })\end{array}$ & $43 P: 16 R$ & $67 \mathrm{P}: 1 \mathrm{R}$ \\
\hline & B 368 & $21 \mathrm{P}: 16 \mathrm{R}$ & - & - & 46P: $10 \mathrm{R}$ & - \\
\hline & B362 & $8 P: 16 R$ & - & - & $21 P: 4 R \ddagger$ & - \\
\hline
\end{tabular}

$\mathbf{P}=$ Parental random isolates $; \mathbf{R}=$ recombinant random isolates $\mathbf{P D}=$ parental ditype asci ; $\mathrm{T}=$ tetratype asci; $\mathrm{NPD}=$ non-parental ditype asci.

* Pooled data from various crosses. Data are not included if sex was scored only in a non-random sample of the isolates, in such a way as might introduce bias.

+ Data of D. D. Perkins.

$\ddagger$ Only $51 \%$ germination. Germination in all other crosses was good.

combinations of heterokaryon-formation (het) genes, rather than to failure of the arginine mutants to complement each other. Garnjobst (1955) showed that, at least in the cases she studied, stable heterokaryons were formed only when the het genes of both strains were alike. On the assumption that all het genes involved here behave in this way, the isolates used for the present tests were all chosen from at least third generation backcrosses to wild type STA, to increase their chances of similarity, and a single isolate of each mutant was used for all tests. Since all mutants of one linkage group gave a positive test with the same isolate of the other group, it seems likely that they were all mutually compatible.

Failure to complement each other has been definitely demonstrated in the critical case of the group VII mutants B317 and B370, by isolation of the heterokaryon-compatible double mutants B370 pan $A$ and $\mathrm{B} 317$ nt $A$. These were tested in growth tubes according to Ryan, Beadle \& Tatum (1943). Neither strain alone grew in the absence of either of its required nutritional supplements; together they grew at wild type rate in each of three tests when only arginine was supplied, but failed to grow in each of three tests when only pantothenate and nicotinamide were present. The experiment was repeated on 
slopes of solid media with similar results. Thus a clearly compatible combination of mutants B370 and B317 was unable to form an $\mathrm{arg}^{+}$heterokaryon.

The classification of mutants described above is confirmed by fertility tests. Crosses between any two mutants of the same group have invariably been semi-sterile. On the best medium found ( $\mathrm{SC}+\mathbf{0} \cdot \mathbf{1} \mathrm{mg}$. L-arginine $\mathrm{HCl} / \mathrm{ml}$.) they formed abundant black perithecia, but ascospore production was low and the vast majority of spores were white and did not germinate. On the other hand, each of the nine mutants was highly fertile when crossed to any other stock tested. Crosses of group I by group VII mutants were also highly fertile in the four combinations tested.

\section{Allelism tests}

From the heterokaryon tests it might be presumed that the members of each of the two groups of arginine mutants are alleles. The near-sterility in intragroup crosses would point to the same conclusion, since sterility in crosses between apparent alleles is a frequent occurrence (see, for example, Mitchell \& Mitchell, 1956; Pritchard, 1955). However, it is probable that both these types of evidence are essentially indications of a biochemical similarity, and, in a study designed to test the one gene-one enzyme hypothesis, decisions on allelism must be based on purely genetic criteria.

Methods. The near-sterility of crosses between mutants of the same group creates a major obstacle to obtaining direct genetic evidence on allelism. Many attempts were made to overcome this problem, with some success. A major cause of the sterility is evidently that the high arginine concentration required for optimal growth $(\mathbf{0} \cdot \mathbf{5}-\mathbf{1} \cdot \mathbf{0} \mathrm{mg}$. L-arginine $\mathrm{HCl} / \mathrm{ml}$.) provides a higher concentration of available nitrogen than is compatible with the production of functional perithecia. The inhibition of perithecium formation by high nitrogen concentrations was described by Hirsch (1954). The best solution to this problem found so far is to make crosses in Petri plates on SC medium (Westergaard $\&$ Mitchell, 1947) containing a suboptimal concentration of arginine, and to add further arginine supplements after fertilization. In practice, $15 \mathrm{ml}$. of medium, usually containing $\mathbf{0} \cdot 1 \mathrm{mg}$. arginine $/ \mathrm{ml}$, was used per plate. The cross was fertilized at 6-7 days, and six or more additions of sterile arginine solution (usually $0.15 \mathrm{ml}$. of a $10 \mathrm{mg} . / \mathrm{ml}$. solution) were made at a single point at the edge of the plate, usually at daily intervals, beginning 1 or 2 days after fertilization. Most of the ripe perithecia appeared in a zone $\frac{1}{2}-1 \frac{1}{2}$ in. from the point of addition, and shot their spores on to the lid of the plate.

This procedure gave a great increase in ascospore production, but little or no improvement in the proportion of ripe spores. As many spores as possible were therefore scraped from the lid, freed from any mycelium growing there, heat-shocked, and plated in sorbose medium to screen for the few which were viable. Initial experiments were done by selective plating, i.e. spores were plated with and without arginine, and the $\%$ of arg ${ }^{+}$mutants estimated from the numbers of colonies on the two types of media. To obtain more accurate values, some experiments were done by 'total isolation', i.e. all spores were plated with arginine, and all adequately separated colonies isolated and tested. 
The same plates were sometimes used both for total isolation and for the estimated viable count on a selective plating.

Approximate information about allelism may also be obtained indirectly by mapping, to determine whether all mutants are in the same region. The results of both methods are given below.

Group I mutants. The direct-crossing method was less successful for group I mutants than for those in group VII. The sparse results for group I are given in Table 3; since no arg $^{+}$colonies were found, it is concluded that mutants 46004, H 4250, B312, and B 369 must at least be closely linked. Crosses B, C, D and $\mathbf{F}$ were analysed as described above. For cross $\mathbf{A}$, the spores were instead heat-shocked on plates of complete medium without sorbose, and the few which germinated isolated and tested. For cross E, single ripe-looking spores were isolated directly. These two methods are too slow to be generally useful.

Table 3. Crosses between group I arginine mutants

\begin{tabular}{|c|c|c|c|c|}
\hline Cross & Parents & $\begin{array}{l}\text { No. of } \\
\text { viable } \\
\text { spores }\end{array}$ & $\begin{array}{l}\text { No. of } \\
\arg ^{+} \\
\text {spores }\end{array}$ & Method \\
\hline A & $46004 \times \mathrm{H}_{4250}$ & 176 & 0 & $\begin{array}{l}\text { Isolation of germinated } \\
\text { ascospores }\end{array}$ \\
\hline $\mathbf{B}$ & $46004 \times \mathrm{H} 4250$ & $27 *$ & 0 & Selective plating \\
\hline $\mathbf{C}$ & $46004 \times 36703 \mathrm{~T}$ & $31 *$ & $\mathbf{0}$ & Selective plating \\
\hline I & $46004 \times$ B312 & $452 *$ & $\mathbf{0}$ & Selective plating \\
\hline $\mathbf{E}$ & $46004 \times$ B312 & 38 & 0 & Random isolates \\
\hline $\mathbf{F}$ & $46004 \times$ B 369 & $148^{*}$ & 0 & Selective plating \\
\hline
\end{tabular}

Because these mutants are located in a well-marked chromosome region, all further study of them was done by mapping. Various crosses of mutant 46004 to known markers showed that it is located between sex and crisp, and very close to $a d-5$. This location suggested close linkage to the marker arg-3 (30300), which can use either citrulline or arginine. Ascospores from a cross of mutants $30300 \times 46004$, plated on sorbose medium, gave only one definite and one questionable $\mathrm{arg}^{+}$colony out of approximately 665 viable spores. To eliminate spurious wild types arising by heterokaryon formation, ascospores from crosses of $30300 \times 46004$ and of 30300 by three other group I mutants were then plated on minimal agar and scored as $\mathrm{arg}^{+}$or $\mathrm{arg}^{-}$by the amount of growth produced shortly after germination, as described by Mitchell, Pittenger \& Mitchell (1952). The rare apparent wild types, both in and out of the counted area, were isolated and retested, and those which proved to be really $\mathrm{arg}^{+}$were scored for sex to obtain information on gene order. Of nineteen putative $\mathrm{arg}^{+}$which were isolated and retested, two were actually arg $^{-}$; therefore any arg $^{+}$which could not be isolated, because of closeness to other spores, were recorded as 'uncertain'. Results to date are summarized in Table 4. They indicate that all four arginine mutations are located within three map units of 30300, and probably between 30300 and sex. It is not yet known whether the lower $\arg ^{+}$frequency found for the $30300 \times 46004$ cross is valid. This cross is more difficult to score, 
so that in this (but not in the other three crosses) occasional arg $^{+}$might go undetected. A cross of mutant 30300 by the fifth group I mutant, H4250, was not scorable by this method.

\section{Table 4. Crosses of 30300 (citrulline) $\times$ group I arginine mutants}

Ascospores classified by growth after germination on minimal agar plates.

\begin{tabular}{|c|c|c|c|c|c|}
\hline \multirow[b]{2}{*}{ Cross } & \multicolumn{2}{|c|}{$\begin{array}{l}\text { No. of } \mathrm{arg}^{+} \text {spores } \\
\text { in counted areas }\end{array}$} & \multirow{2}{*}{$\begin{array}{l}\text { Total } \\
\text { germinated } \\
\text { spores in } \\
\text { counted } \\
\text { area }\end{array}$} & \multirow{2}{*}{$\begin{array}{c}\% \\
\arg ^{+}\end{array}$} & \multirow{2}{*}{$\begin{array}{c}\text { Sex of } \\
\text { certain } \text { arg }^{+} \\
\text {(not restricted } \\
\text { to counted area) }\end{array}$} \\
\hline & Certain & Uncertain & & & \\
\hline $30300 \mathrm{a} \times 46004 \mathrm{~A}$ & 2 & $\mathbf{1}^{*}$ & c. 4300 & $0.05-0.07$ & $2 \mathrm{a}, 0 \mathrm{~A}$ \\
\hline $30300 \mathrm{a} \times \mathrm{B312 \textrm {A }}$ & 4 & $2 \dagger$ & 409 & $1 \cdot 0-1 \cdot 5$ & $4 \mathrm{a}, 1 \mathrm{~A}$ \\
\hline $30300 \mathrm{a} \times \mathrm{B369A} \ddagger$ & 3 & $5 *$ & 611 & $0 \cdot 5-1 \cdot 3$ & $7 \mathbf{a}, 1 \mathrm{~A}$ \\
\hline $30300 \mathrm{a} \times 36703 \mathrm{~T}^{+} \mathrm{A}$ & 2 & $1 *$ & 468 & $0 \cdot 4-0 \cdot 6$ & $2 \mathrm{a}, 0 \mathrm{~A}$ \\
\hline
\end{tabular}

Group VII mutants. The first crosses between mutants in this group gave an unexpected result: many arg $^{+}$progeny were obtained from each combination tested; namely, B370 $\times \mathrm{B362}$, B370 $\times \mathrm{B368}$, and B370 $\times \mathrm{B317}$ (Table 6, first three lines). On the face of it, this would mean that the enzyme argininosuccinase was controlled by widely separated loci. However, in view of the data in Table 2 (which indicate rather close linkage), and also of the possible single origin of strains B362, B368 and B370, this explanation seemed so unlikely that it was suspected that the arginine-independent colonies arose from some cause other than crossing over, e.g. reversion or contamination, or that they were really only pseudo-wild types, as described by Mitchell $e t a l$. (1952).

Because of the great labour required to produce enough ripe spores to settle this question, further $\mathrm{arg}^{-} \times \mathrm{arg}^{-}$crosses were confined to the single combination of strains B370 $\times$ B 317. At the same time, careful mapping of each of these mutants was begun; the results showed clearly that B 370 and B317 were at most a few units apart, and might well be alleles. The results of the $\mathrm{arg}^{-} \times \mathrm{arg}^{-}$ crosses showed almost equally clearly that the $\mathrm{arg}^{+}$progeny were nevertheless true recombinants; their high frequency apparently is due to selective ripening of ascospores. The two mutants must therefore be either pseudoallelic or closely linked. The evidence is as follows.

The mapping consisted of a series of three-point crosses, each involving an arginine mutant plus the two closest markers, $b n$ and $n t$. The results are given in Table 5. It is clear that for both arginine mutants the order is bn--arg--nt. In one cross the distance $\arg (B 316)--n t$ is somewhat greater than the average value for $\arg (B 370)--n t$, but it is questionable whether this difference is real, considering the wide variation between crosses. Similar variations between crosses in different genetic backgrounds have been noted in Neurospora by Stadler (1956), and by F. de Serres, R. W. Barratt, and others (personal com- 
munications). In any case $\mathrm{B} 370$ and $\mathrm{B} 317$ are most probably between 0 and 6 units apart.

\section{Table 5. Group VII three-point crosses}

Numbers of random isolates from crosses involving the markers button (B40), arginine (either B317 or B370), and nicotinic acid + tryptophan (65001).

\begin{tabular}{|c|c|c|c|c|}
\hline \multirow{3}{*}{$\begin{array}{c}\text { Parent genotypes } \\
+\arg n t \\
b n++\end{array}$} & \multirow{3}{*}{$\begin{array}{l}\begin{array}{l}\text { Parental } \\
\text { combinations }\end{array} \\
43+-\overline{-} \\
36-++ \\
79\end{array}$} & \multicolumn{3}{|c|}{ Recombinations } \\
\hline & & $\begin{array}{l}\text { Singles } \\
\text { region } 1 \\
(b n \text {-arg })\end{array}$ & $\begin{array}{c}\text { Singles, } \\
\text { region } 2 \\
(\text { arg- } n t)\end{array}$ & $\begin{array}{l}\text { Doubles, } \\
\text { regions } 1 \\
\text { and } 2\end{array}$ \\
\hline & & $\begin{array}{l}7+++ \\
4--- \\
11 \\
(12 \cdot 0 \%)\end{array}$ & $\begin{array}{l}2+-+ \\
0-+- \\
2 \\
(2 \cdot 2 \%)\end{array}$ & $\begin{array}{l}0++- \\
0--+\end{array}$ \\
\hline$\frac{+\arg n t}{b n++}(\arg =\mathrm{B} 317)$ & $\begin{array}{l}38+-- \\
37-++ \\
75\end{array}$ & $\begin{array}{l}5+++ \\
6--- \\
11 \\
(12 \cdot 6 \%)\end{array}$ & $\begin{array}{l}1+-+ \\
0-+- \\
1 \\
(1 \cdot 2 \%)\end{array}$ & $\begin{array}{l}0++- \\
0--+\end{array}$ \\
\hline$\frac{+++}{b n \arg n t}(\arg =\mathrm{B} 370)$ & $\begin{array}{l}79+++ \\
60--- \\
139\end{array}$ & $\begin{array}{l}22+-\overline{ } \\
14-++ \\
36 \\
(20 \cdot 0 \%)\end{array}$ & $\begin{array}{l}1++- \\
3--+ \\
4 \\
(2 \cdot 2 \%)\end{array}$ & $\begin{array}{l}1+-+ \\
0-+- \\
1 \\
(0 \cdot 6 \%)\end{array}$ \\
\hline$\frac{+\arg +}{b n+\frac{1}{n t}}(\arg =\mathbf{B} 370)$ & $\begin{array}{l}36+-+ \\
29-+- \\
65\end{array}$ & $\begin{array}{l}15++- \\
9--+ \\
24 \\
(26 \cdot 4 \%)\end{array}$ & $\begin{array}{l}0+-\overline{+} \\
2-++ \\
2 \\
(2 \cdot 2 \%)\end{array}$ & $\begin{array}{l}0+++ \\
0---\end{array}$ \\
\hline$\frac{+a r g+}{b n+n t}(a r g=\mathbf{B 3 1 7})$ & $\begin{array}{l}31+-+ \\
31-+- \\
63\end{array}$ & $\begin{array}{l}8++- \\
11--+ \\
19 \\
(21 \cdot 6 \%)\end{array}$ & $\begin{array}{l}4+-- \\
3-++ \\
7 \\
(8 \cdot 0 \%)\end{array}$ & $\begin{array}{l}0+++ \\
0---\end{array}$ \\
\hline
\end{tabular}

Results of the arg- $^{-} \times$arg- $^{-}$crosses are given in Tables 6 and 7. All crosses involving two different arginine mutants, i.e. $\mathrm{B} 370 \times \mathrm{B} 317$, will be called intercrosses (IC), and all crosses homozygous for one arginine mutant, e.g. B370 $\times$ B 370, will be called selfings (S), regardless of the distribution of the marker $n t$. The results make highly improbable all obvious origins of the arg $^{+}$progeny other than crossing over.

A high rate of reversion (or suppressor mutation) is eliminated by the absence of arg $^{+}$progeny in the selfings. Selfings appear to be even less fertile than intercrosses; nevertheless, the few data it has been possible to obtain are sufficient to eliminate sampling error. $\boldsymbol{P}$ for homogeneity of either selfing with pooled intercrosses, by $\chi^{2}$ test on the 'total isolation' figures, is $<<0.001$. All isolates from the selfings were tested twice to insure that the rare $\mathrm{arg}^{+}$was not overlooked. It was also shown, by plating IC 7 at different spore concentrations, that the absence of $\mathrm{arg}^{+}$in the selfings was not due to any effect of population density on their survival. Tests for reversion during vegetative growth were also negative.

The results might still be explained by rare reversion, which by chance affected only the cultures used for the intercrosses, followed by selection for the arg $^{+}$progeny. This explanation seems unlikely because several different isolates 
Table 6. Crosses between group VII arginine mutants

\begin{tabular}{|c|c|c|c|c|c|c|c|c|}
\hline \multirow[b]{2}{*}{$\begin{array}{c}\text { Cross } \\
\text { number }\end{array}$} & \multirow[b]{2}{*}{ Parents } & \multicolumn{4}{|c|}{ Total isolation } & \multicolumn{3}{|c|}{ Selective plating } \\
\hline & & $\begin{array}{c}\text { Total } \\
\text { colonies }\end{array}$ & $\begin{array}{c}\text { Total } \\
\text { isolated }\end{array}$ & $\begin{array}{c}\text { No. of } \\
\text { arg }^{+} \\
\text {isolated }\end{array}$ & $\begin{array}{l}\% \text { arg }^{+} \\
\text {among } \\
\text { those } \\
\text { isolated }\end{array}$ & $\begin{array}{l}\text { Esti- } \\
\text { mated } \\
\text { total } \\
\text { viable }\end{array}$ & $\begin{array}{c}\text { No. of } \\
\text { arg }^{+}\end{array}$ & $\begin{array}{c}\arg ^{+} \\
\text {isolate } \\
(c . \%)\end{array}$ \\
\hline ICI & $\mathrm{B370} \times \mathrm{B362}$ & - & - & - & - & 400 & 37 & 9 \\
\hline IC 2 & B370 $\times$ B 368 & $\ldots$ & - & - & - & 490 & 11 & 2 \\
\hline IC3 & B370 $\times$ B 317 & - & - & - & - & 196 & 25 & 13 \\
\hline IC 4 & B370 $\times$ B317 & - & - & - & - & 102 & 17 & 17 \\
\hline IC 5 & $\mathrm{~B} 317 \times \mathrm{B} 370 n t$ & 6 & 4 & 1 & $25 \cdot 0$ & 21 & 7 & 33 \\
\hline IC 6 & B370 × B317 & 497 & 212 & 93 & $43 \cdot 8$ & - & - & 一 \\
\hline $\mathrm{IC} 7$ & $\mathrm{~B} 317 \times \mathrm{B} 370 n t$ & 62 & 41 & 17 & $41 \cdot 5$ & - & - & - \\
\hline IC 8 & $\mathrm{~B} 370 \times \mathrm{B} 317 n t$ & 29 & 27 & 17 & $63 \cdot 0$ & 29 & 11 & 38 \\
\hline IC9 & $\mathrm{B} 370 \times \mathrm{B} 317 n t$ & 10 & 10 & 4 & $40 \cdot 0$ & 8 & 6 & 75 \\
\hline S1 & $\mathrm{B} 370 \times \mathrm{B} 370$ & 9 & 9 & $\mathbf{0}$ & 0 & 一 & - & - \\
\hline S2 & $\mathrm{B} 370 \times \mathrm{B370} n t$ & 44 & 38 & 0 & $\mathbf{0}$ & - & - & 一 \\
\hline S3 & $\mathrm{B} 317 \times \mathrm{B} 317 n t$ & 36 & 32 & 0 & $\mathbf{0}$ & 18 & 0 & o \\
\hline $\mathbf{S} 4$ & $\mathrm{~B} 317 n t \times \mathrm{B} 317 n t$ & 6 & 6 & $\mathbf{0}$ & $\mathbf{0}$ & - & - & - \\
\hline
\end{tabular}

Selective plating gives only a rough estimate of the $\%$ arg+ isolates when the number of viable spores is so small, particularly since the viable count must be based on very few plates. Total isolation is not subject to these errors.

In IC 7, 8 and 9, a dark ascospore could be seen in 52 of the 78 colonies isolated; $50.0 \%$ of those with visible dark spores were $\mathrm{arg}^{+}$, compared to $48 \cdot 7 \%$ of the total.

For crosses carrying $n t$ (65001), excess nicotinamide was added to all plates.

All spores were obtained by the plate-crossing method. The yield of viable spores per cross-plate varied from 5 to 22 for selfings and from 14 to 124 for intercrosses made under comparable conditions.

were used, and because both isolates used as parents for IC7 were also used as parents for S2 and S3.

Contamination during plating of ascospores is excluded because most colonies could be seen microscopically to have arisen from a dark ascospore. For IC7, 8, and 9, the numbers of colonies in which the spore could be seen were counted separately ('Table 6); they yielded approximately the same arg $^{+}$ frequency as did the total data.

Contamination during ascospore formation seems very unlikely, because of the high reproducibility of the results, and because intercrosses heterozygous for $n t$ always gave some $\arg ^{+} n t^{-}$progeny (Table 7 ).

Tests for pseudo-wild types were carried out on eleven representative arg $^{+}$ isolates from the $\mathrm{B} 370 \times \mathrm{B} 317$ crosses, including two $\mathrm{arg}^{+} \mathrm{nt}^{-}$from colonies with visible dark ascospores. These were crossed to standard wild types and usually tested by isolating $\mathbf{5 0}$ spores at random, since the group VII arginine mutants are hard to score on minimal agar plates. No $\mathrm{arg}^{-}$progeny were found in any case. Therefore the $11 \mathrm{arg}^{+}$tested are not pseudo-wild types, and on statistical grounds it is likely that the same holds for most of those not tested.

Heterokaryon formation is eliminated by the double-mutant heterokaryon tests described earlier, and also by the pseudo-wild type tests. Non-genetic adaptation is excluded by the absence of $\mathrm{arg}^{+}$progeny in the selfings, and by the pseudo-wild type tests. 
Thus all obvious origins of the arg $^{+}$progeny other than recombination are virtually eliminated. Recombination is also indicated by the data on the segregation of $n t$ (Table 7 ). However, the true recombination frequency can not be reflected by the frequency of the $\mathrm{arg}^{+}$progeny, since this would require an unprecedented $90 \%$ recombination, which is in any case excluded by the three-point cross data. The only simple explanation would seem to be selection.

\section{Table 7. Segregation of nt in group VII intercrosses}

All adequately separated arg $^{+}$colonies from selective platings were isolated, and their results added to those from the total isolations; the results obtained by the two methods were homogeneous in all cases. The arg- classes are included to show that the skewing in the $\arg ^{+}$classes is not due to selection for or against $n t^{-}$.

\begin{tabular}{|c|c|c|c|c|c|c|}
\hline & \multicolumn{3}{|c|}{$\mathrm{B} 370 \times \mathrm{B3} 17 n t$} & \multicolumn{3}{|c|}{$\mathrm{B370} n t \times \mathrm{B} 317$} \\
\hline & IC 8* & IC 9* & Total & $\mathrm{IC} 7 *$ & $\mathrm{IC5} \dagger$ & Total \\
\hline $\arg +n t^{+}$ & 20 & 4 & 24 & 3 & 2 & 5 \\
\hline $\arg ^{+} n t^{-}$ & 4 & 6 & 10 & 14 & 6 & 20 \\
\hline $\arg ^{-} n t^{+}$ & 4 & 2 & 6 & 16 & o & 16 \\
\hline $\arg ^{-} n t^{-}$ & 6 & 4 & 10 & 8 & 3 & 11 \\
\hline
\end{tabular}

Indeed, there is reason to believe that the near-sterility of these crosses is largely due to a deficiency of arginine inside the perithecia. If, because of this deficit, only $\mathrm{arg}^{+}$spores and their closest $\mathrm{arg}^{-}$neighbours were able to ripen, there might be intense selection for $\mathrm{arg}^{+}$. It is hard to make an accurate estimate of ascospore viability because the unripe spores are nearly transparent; a very rough count for the cross IC 6 indicated that only about $0.067 \%$ of the shot ascospores survived. If all the non-viable spores were arg $^{-}$, the true arg + frequency would be only $0.023 \%$; i.e. within the range for crossing over between pseudoalleles.

Since the $\mathrm{arg}^{+}$isolates evidently do arise by recombination, it is of interest to know whether the process results in restoration of the wild-type enzyme, and whether any trace of the arginine requirement remains. Drs Fincham \& Boylen (personal communication) have tested six representative $\mathrm{arg}^{+}$isolates from the $\mathrm{B} 370 \times \mathrm{B3I} 7$ crosses, including two $\mathrm{arg}^{+} n \mathrm{t}^{-}$which had been tested for pseudo-wild types. All of them had argininosuccinase activity like that of the standard wild type. Also, three $\mathrm{arg}^{+} n \mathrm{t}^{+}$isolates were tested in flask cultures. Dry-weight determinations showed that arginine was not significantly more stimulatory for these isolates than for the standard wild-type controls.

\section{DISCUSSION}

The sterility problem has prevented localization of either group of mutants to an interval of less than a few map units. For the group VII mutants it obviously is not feasible to go further until better markers or a better crossing method become available; indeed, the analysis would never have been continued this far, had it not been necessary in order to give meaning to the 
enzymic studies. The group I mutants, on the other hand, warrant further study, since an abundance of close markers partly compensates for the sterility of intra-group crosses.

Despite the technical difficulties, this investigation has been fruitful in two respects. First, the group VII mutants provide a new case in which major control of a biosynthetic enzyme is apparently restricted to a small chromosome region, and it seems likely that the group I mutants will add still another case when enzymic tests are completed. Previous work on biosynthetic enzymes suggests that, although changes at various loci can cause minor changes in activity of the same enzyme (Hogness \& Mitchell, 1954; Yanofsky \& Bonner, 1955), there is only one locus at which mutation can cause a deficiency so severe that it results in a nutrient requirement (tryptophan synthetase: Yanofsky \& Bonner, 1955; and Weijer, 1954; glutamic dehydrogenase: Fincham, 1950, 1954). In the case of catabolic enzymes on the other hand, it is clear that severe enzymic deficiencies can be caused by mutations at numerous widely separated loci (lactase: Lederberg, 1951; O. Landman, cited in Bonner, 1951 ; tyrosinase: Markert, 1950). It appears that many of these loci act by controlling the production of other proteins needed for the induction of the enzyme itself (Monod, 1956; Landman, cited in Bonner, 1951), and it is perhaps reasonable that catabolic enzymes should be more subject than biosynthetic ones to such multi-gene control. The question remains whether the distinction between the two types of enzyme has any validity, or whether it merely results from the very small number of biosynthetic enzymes for which more than one mutant has been tested. The present two cases support the idea that the distinction is real, even though neither group of arginine mutants is localized to as small a chromosome region as would be desirable.

This investigation also provides a second case, in addition to tryptophan synthetase, in which mutants which cause the loss of the same biosynthetic enzyme are apparently separable by infrequent crossing over. However, the recent work of Lindegren (1955) and Mitchell (1955) raises the possibility that the apparent recombinants are really due to 'gene conversion'. 'The data in Table 7 indicate an excess of apparent double cross-overs like that found in several studies of complex loci (e.g. Pritchard, 1955; Mitchell, 1955; St Lawrence, 1956; Giles, 1956). In Mitchell's case (but not in Pritchard's) these proved to be due to conversion rather than recombination. With present methods it seems impossible to eliminate conversion in the case of either argininosuccinase or tryptophan synthetase. Until it is eliminated in a case which can be studied enzymically, direct evidence that pseudoalleles can govern the same enzyme will be lacking.

This investigation was supported in part by a research grant, No. C2167, from the National Cancer Institute of the National Institutes of Health, U.S. Public Health Service. Part of the work was done in the Genetics Department, The University of Glasgow, and the hospitality of Prof. G. Pontecorvo is gratefully acknowledged. The author is indebted to Mrs Eivor Högström for technical assistance. 


\section{REFERENCES}

Barratt, R. W., Newmeyer, D., Perkins, D. D. \& Garnjobst, L. (1954). Map construction in Neurospora crassa. Advanc. Genet. 6, 1.

Beadle, G. W. (1945). Biochemical Genetics. Chem. Rev. 37, 15.

Beadle, G. W. \& Tatum, E. L. (1945). Neurospora. II. Methods of producing and detecting mutations concerned with nutritional requirements. Amer. J. Bot. $32,678$.

Bonner, D. M. (1951). Gene-enzyme relationships in Neurospora. Cold. Spr. Harb. Symp. quant. Biol. 16, 143.

Fincham, J. R. S. (1950). Mutant strains of Neurospora deficient in animating ability. J. biol. Chem. 182, 61.

FinchaM, J. R. S. (1954). Effects of a gene mutation in Neurospora crassa relating to glumatic dehydrogenase formation. J. gen. Microbiol. 11, 236.

Fincham, J. R. S. \& Boylen, J. B. (1957). Neurospora crassa mutants lacking argininosuccinase. J. gen. Microbiol. 16, 438.

Garnjosst, L. (1955). Further analysis of genetic control of heterocaryosis in Neurospora crassa. Amer. J. Bot. 42, 444.

GrLes, N. H. (1956). Forward and back mutation at specific loci in Neurospora. Brookhaven Symp. Biol. 8, 103.

Hirsch, H. M. (1954). Environmental factors influencing the differentiation of protoperithecia and their relation to tyrosinase and melanin formation in Neurospora crassa. Physiol. Plant. 7, 72.

Hogness, D. S. \& MrTchell, H. K. (1954). Genetic factors influencing the activity of tryptophan desmolase in Neurospora crassa. J. gen. Microbiol. 11, 401.

Hungate, F. P. \& Mannell, T. J. (1952). Sulfur-35 as a mutagenic agent in Neurospora. Genetics, 37, 709.

LADERBERG, J. (1951). Genetic studies with bacteria. In Genetics in the 20th Century, p. 263, ed. by L. C. Dunn. New York: Macmillan.

LEwis, E. B. (1955). Some aspects of position pseudoallelism. Amer. Nat. 89, 73.

Lindegren, C. C. (1955). Non-Mendelian segregation in a single tetrad of Saccharomyces ascribed to gene conversion. Science, 121, 605.

Markert, C. L. (1950). The effect of genetic changes on tyrosinase activity in Glomerella. Genetics, 35, 60.

Mrtchell, M. B. (1955). Aberrant recombination of pyridoxine mutants of Neurospora. Proc. nat. Acad. Sci., Wash. 41, 215.

Mitchell, M. B. \& Mitchell, H. K. (1952). Observations on the behaviour of suppressors in Neurospora. Proc. nat. Acad. Sci., Wash. 38, 205.

Mrtchell, M. B. \& Mitcheld, H. K. (1956). Tests for non-allelism at the pyrimidine-3 locus of Neurospora. Genetics, 41, 319.

Mitchell, M. B., Pittenger, T. H. \& Mitchell, H. K. (1952). Pseudo-wild types in Neurospora crassa. Proc. nat. Acad. Sci., Wash. 38, 569.

Monod, J. (1956). Remarks on the mechanism of enzyme induction. In Enzymes: Units of Biological Structure and Function, p. 7, ed. by O. H. Gaebler. New York: Academic Press Inc.

Newmeyer, D. (1954). A plating method for genetic analysis in Neurospora. Genetics, 39, 604 .

Ponteconvo, G. (1955). Gene structure and action in relation to heterosis. Proc. Roy. Soc. B, 144, 171.

Pritchard, R. H. (1955). The linear arrangement of a series of alleles of Aspergillus nidulans. Heredity, 9, 343.

Ratner, S., Anslow, W. P., Jun. \& Petrack, B. (1953). Biosynthesis of urea. VI. Enzymatic clevage of argininosuccinic acid to arginine and fumaric acid. J. biol. Chem. 204, 115. 
Ratner, S. \& Petrack, B. (1953). Biosynthesis of urea. IV. Further studies on condensation in arginine synthesis from citrulline. J. biol. Chem. 200, 161.

Ryan, F. J., Beadle, G. W. \& Tatum, E. L. (1943). The tube method of measuring the growth rate of Neurospora. Amer. J. Bot. 30, 784.

Singleton, J. R. (1948). Cytogenetic Studies of Neurospora crassa. Ph.D. thesis, California Institute of Technology.

Snв, A. M. (1946). Ornithine-arginine Metabolism in Neurospora and its Genetic Control. Ph.D. thesis, Stanford University.

SRB, A. M. \& Horowitz, N. H. (1944). The ornithine cycle in Neurospora and its genetic control. J. biol. Chem. 154, 129.

Stadler, D. R. (1956). A map of linkage group VI of Neurospora crassa. Genetics, $41,528$.

St Lawrence, P. (1956). The $q$ locus of Neurospora crassa. Proc. nat. Acad. Sci., Wash. 42, 189.

Tatum, E. L., Barratt, R. W., Fries, N. \& Bonner, D. (1950). Biochemical mutant strains of Neurospora produced by physical and chemical treatment. Amer. $J$. Bot. 37, 38.

WhLKer, J. B. \& Myers, J. (1953). The formation of argininosuccinic acid from arginine and fumarate. J. biol. Chem. 203, 143.

WeIJER, J. (1954). A genetical investigation into the TD-locus of Neurospora crassa Genetica, 28, 173.

WestergaArd, M. \& Mitcheli, H. K. (1947). Neurospora. V. A synthetic medium favoring sexual reproduction. Amer. J. Bot. 34, 573.

YANOFSKy, C. \& BonNER, D. M. (1955). Gene interaction in tryptophan synthetase formation. Genetics, $\mathbf{4 0 ,} \mathbf{7 6 1}$.

(Received 18 October 1956) 